Article

\title{
In-Between Sprawl and Neo-Rurality: Sparse Settlements and the Evolution of Socio-Demographic Local Context in a Mediterranean Region
}

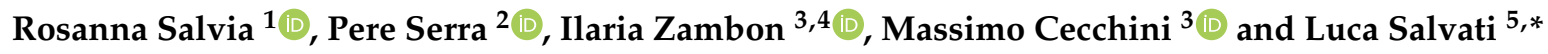 \\ 1 Department of Mathematics, Computer Science and Economics, University of Basilicata, \\ Via dell'Ateneo Lucano, I-85100 Potenza, Italy; rosanna.salvia@unibas.it \\ 2 Department of Geography, Autonomous University of Barcelona, Building B, Campus UAB, ES-08193 \\ Bellaterra (Cerdanyola del Vallès), Barcelona, Spain; pere.serra@uab.cat \\ 3 Department of Agricultural and Forestry Sciences (DAFNE), Tuscia University, Via San Camillo de Lellis, 5, \\ I-01100 Viterbo, Italy; ilaria.zambon@unitus.it (I.Z.); cecchini@unitus.it (M.C.) \\ 4 Soil Erosion and Degradation Research Group, Department of Geography, University of Valencia, \\ ES-46010 Valencia, Spain \\ 5 Council of Agricultural Research and Economics (CREA), Research Centre for Forestry and Wood, \\ Viale S. Margherita 80, I-52100 Arezzo, Italy \\ * Correspondence: luca.salvati@crea.gov.it
}

Received: 11 September 2018; Accepted: 11 October 2018; Published: 14 October 2018 updates

\begin{abstract}
Dispersed urbanization during the last half century has transformed metropolitan regions into well-connected, low-density residential areas. However, this kind of urbanization has changed irreversibly the traditional rural landscape around cities, leading to a new definition of 'rurality'. The present work discusses the intimate relationship between urban sprawl and new forms of rurality. Considering economic downturns and the possible impact on landscape transformations, our study focuses on a representative Mediterranean case of urban sprawl (the metropolitan region of Athens, Greece). In this area, urban settlements expanded rapidly into fringe land, producing relevant socio-demographic transformations that have determined uneven changes in rural landscapes. A spatially-explicit investigation of local-scale dynamics that characterize population residing in sparse settlements over a long time period (1961-2011) —encompassing distinct phases of urban growth and rural development-is relevant for analysis of local changes in the relationship between sprawl and new forms of rurality. A new concept of 'rurality' —adapting to rapidly-evolving, mixed rural/peri-urban contexts-require reframing the relationship between rural landscapes, scattered settlements, economic cycles and socio-demographic aspects, in the light of a truly sustainable development of local territories.
\end{abstract}

Keywords: landscape; olive; metropolitan area; sustainable land management

\section{Introduction}

During the last half century, urban sprawl has progressively transformed metropolitan regions into well-connected and low-density residential areas [1-7]. This recent kind of urbanization has intensively changed the traditional rural landscape, leading to a new definition of 'rurality' [1,3,8-18]. Transformation of agricultural landscapes—and particularly farmland abandonment—are widespread land-use changes in many European regions, due to increasing yields on productive land, conservation policies and the increasing import of agricultural products from other regions [14,19-23]. Among the most relevant consequences, land consumption due to residential development and economic growth 
became one of the most thoughtful environmental pressures on landscapes, especially in metropolitan areas [24-26].

A sustainable land management strategy for metropolitan regions is increasingly required to quantify long-term and short-term land-use changes, recognizing trends in their main drivers [27-31]. Because of multifaceted social processes, land-use changes involve multiple interacting actors [32]. Since the early 1980s, Mediterranean cities have experienced a rapid transition from mostly compact and dense settlement models to various steps of a more discontinuous morphology characterized by huge expansion around inner cities [33]. Trends toward 'compact growth' observed up to the early 1990s and the following 'discontinuous urbanization' have affected land-use structure and peri-urban farming in a different way $[5,16,26,28,34]$. How the changing land-use represents a target for policies mitigating soil consumption and promoting peri-urban agriculture in Mediterranean fringes has been discussed [16,25,27,35-39], although empirical evidence from different socioeconomic contexts is still required. With the final objective to define a new concept of 'rurality' for territorial contexts characterized by dispersed urban settlements (e.g., urban sprawl), indicator-based quantitative approaches are essential for understanding local transformations which alter the traditional urban-rural gradient typical of mono-centric cities in the Mediterranean region, allowing identification of new central and peripheral places, and the respective changes over time [29,40-42].

Based on these premises, the present study focuses on a Southern European case study (Athens, Greece) investigating the latent relationship between sparse (rural) settlements and the evolution of the respective socio-demographic local context. Athens can be considered a Mediterranean compact city [43-45], where a long-term urban development occurred alternating settlement densification and dispersion in a framework of planning deregulation [46-53]. However, the most recent expansion was the result of relatively strict planning regulations that were relaxed with the aim to facilitate and speed up the construction of Olympic infrastructures, (urban and peri-urban) road and railways networks and the new international airport. At the same time, the recent Athens expansion provides a peculiar contribution to Mediterranean urban history; according to Di Feliciantonio and Salvati [44], "urban diffusion processes vary widely according to the context, as does the socio-economic profile of the actors, stressing the need to think about different 'southern European alternatives' of sprawl. ( ... ) In the case of Athens, the main actors of urban diffusion appear to be medium-upper class, white-collar households", suggesting the inherent complexity and specificity of the case study.

By considering together territorial and socioeconomic transformations, settlement expansion and infrastructural development in a metropolitan system moving from economic expansion to crisis $[1,17,54]$, the present work focuses on the intrinsic relation between sprawl and new spatial configurations of rural landscapes, possibly reflecting a new concept of 'rurality' in Mediterranean Europe. With economic crisis, workers have experienced falling incomes and contraction of public services; unemployment and urban poverty have alimented the so-called 'back to the land' movements, reconstructing the condition for a 'new rurality' [55]. A spatially-explicit investigation of local-scale dynamics of population living in sparse settlements over different phases of urban growth and rural development (1961-2011) contributes to exploring such changes in a region more recently undergoing recession and experiencing austerity urbanism, such as Attica (Greece). Under the assumption that rural mobility is often linked to urban processes [10,55-57], the adopted approach aims at providing a comprehensive outline of the rapidly-evolving socioeconomic conditions in Athens, the capital of Greece, over different time intervals in recent urban history [58]. Based on the results of this study, notions such as 'rurality' and 'rural development' can be discussed within a new framework considering together urban sprawl, counter-urbanization and rural migration processes [59]; in this regard, residential mobility is intimately related with specific socioeconomic attributes in turn shaping counter-urbanization, increasingly seen as an ideological and political issue [60-62]. 


\section{Methodology}

\subsection{Study Area}

The investigated area includes the Athens metropolitan region that extends more than $3000 \mathrm{~km}^{2}$ of land administered by the regional authority of Attica (Greece). The region was partitioned into four prefectures (Athens, Eastern Attica, Western Attica and Piraeus) and 114 municipalities of which 58 are classified as urban municipalities (and coincide with the Greater Athens' area) and 56 municipalities as rural (located in the surroundings of the Greater Athens' area). The investigated area consists of uplands bordering the flat district of Greater Athens and the rural plains along the Aegean Sea coast (Messoghia, Marathon and Thriasio). The prevailing climate regime in the area is Mediterranean dry, with annual rainfall ranging between 350 and $700 \mathrm{~mm}$ and average air temperatures around $17-19^{\circ} \mathrm{C}$ on an annual basis. Although specialized in Mediterranean dry crop systems (olive trees and vineyards), the area underwent rapid and continuous urban growth over the last two centuries $[4,63,64]$. Being the most densely populated region in Greece (nearly 4400 inhabitants $/ \mathrm{km}^{2}$ in 2011), with the largest increase in population density at the country scale ( +2900 inhabitants $/ \mathrm{km}^{2}$ between 1951 and 2011), the area experienced massive suburbanization since the early 1980s, with a progressive expansion of discontinuous fringe settlements [47]. Rural districts of Messoghia and Thriasio were involved in a latent process of urban growth stimulated by real estate speculation and increasing (public and private) investments during the Olympic decade [48]. Progressive urbanization has contributed to altering the traditional relationships between farmers and the related territory, giving rise to new forms of 'rurality'. Since the late 2000s, Attica has experienced an intense economic crisis, in line with what happened in other Mediterranean cities $[10,26,51,65,66]$. In this socioeconomic context, counter-urbanization was sometimes observed [49], fueling social movements that promote a coming back to the land for young unemployed and poor working classes $[60,67]$. These factors may justify the adoption of Athens as a paradigmatic case of new forms of 'rurality' in a transforming peri-urban context under a recessionary stage.

\subsection{Statistical Indicators}

Statistical data aggregated at the municipal scale and derived from the General Censuses of Population and Households held every 10 years between 1951 and 2011 by Hellenic Statistical Authority (hereafter ELSTAT) were considered when designing indicators that assess size and extent of sparse settlements at an enough detailed geographical scale. Municipalities were selected as the elementary analysis unit for a spatially-explicit investigation of local-scale dynamics of population living in sparse settlements over a long-term period encompassing different phases of urban growth and rural development in Attica. For each municipality, census data allowed quantification of population (i) residing in central settlements (the compact center giving the name to each municipality) and (ii) living in sparse settlements; these settlements are physically separated from the core settlements and are scattered across the municipal territory. A specific indicator estimating the size of sparse population at each census date was calculated as the percent share of population living in sparse settlements in total population residing in each municipality. This indicator may outline the spatial characteristics of farming systems and the related pattern of population distribution. In contexts with traditional rural areas, sparse settlements may host a relatively large population in respect with the corresponding center. With important transformations in rural districts (e.g., urban expansion), population living in sparse settlements may decrease, leading to more polarized settlements, e.g., separating high-density locations from (totally or partially) abandoned areas which are no longer cultivated $[13,18,23,34]$.

Additional indicators were considered here with the aim to assess the basic characteristics of the socio-demographic local contexts between 1961 and 2011. A coherent and homogeneous set of contextual indicators was unavailable for the first decade of study (the early 1950s). Indicators were calculated from official datasets based on ELSTAT censuses and public registers or other national/international statistical sources and include: (i) average farm size (hereafter 'Afs'), 
(ii) population growth rate (\% per year, ' $\mathrm{g}$ '), (iii) forest land in total landscape $(\%$, ' $\mathrm{f}$ '), (iv) protected areas (' $\mathrm{p}$ '), (v) residential buildings in total building stock $\left(\%,{ }^{\prime} \mathrm{r}\right.$ '), (vi) industrial buildings in total building stock $\left(\%,{ }^{\prime}{ }^{\prime}\right)$, (vii) buildings with tourism use in total building stock $\left(\%, ' t^{\prime}\right)$, (viii) commerce/service buildings in total building stock (\%, 'e'), (ix) multiple usage buildings in total building stock $\left(\%, \mathrm{~m}^{\prime}\right)$, (x) diversity in building use (' $\mathrm{u}$ '), (xi) municipal town plan enforced in law (dummy variable, ' $\mathrm{o}$ '), (xii) average elevation ( $\mathrm{m}$, 'Ele'), (xiii) proximity to the sea coast line (dummy variable, 'Sea'), (xiv-xix) distances from Athens ('dAth'), Piraeus ('dPir'), Maroussi ('dMar'), Markopoulo Messoghias ('dMak'), Aspropyrgos ('dAsp') and Oropos ('dOro'), intended as relevant urban centers (or sub-centers) in the study area (Figure 1), (xx) municipal size (log ha, 'Area'), (xxi) Soil quality index ('Sqi') and (xxii) Climate quality index ('Cqi'). Distances from urban centers and sub-centers mentioned above were calculated as the linear distance between the relevant municipal centroids. This analysis provided a generalized picture of spatial relationships, distances and accessibility characterizing the study area [42]. The adopted indicators provide a comprehensive overview of rapidly evolving socioeconomic conditions in Athens' fringe over the entire study period. Since they were derived from statistical data, mainly from national censuses of population and agriculture, indicators' homogeneity, representativeness and comparability over time is the highest possible within quantitative information provided by official statistics. The number of municipalities in the study area was increasing slightly over the time period stabilizing at the actual number in 1971 and 1981. In this regard, we developed a full indicators' database covering all the spatial domains for six points in time, from 1961 to 2011. The few missing data were filled considering (i) the value observed for the same municipality ten years later, (ii) the values of the four neighboring municipalities and (iii) the cross-section, average value of the same indicator in the entire study area.

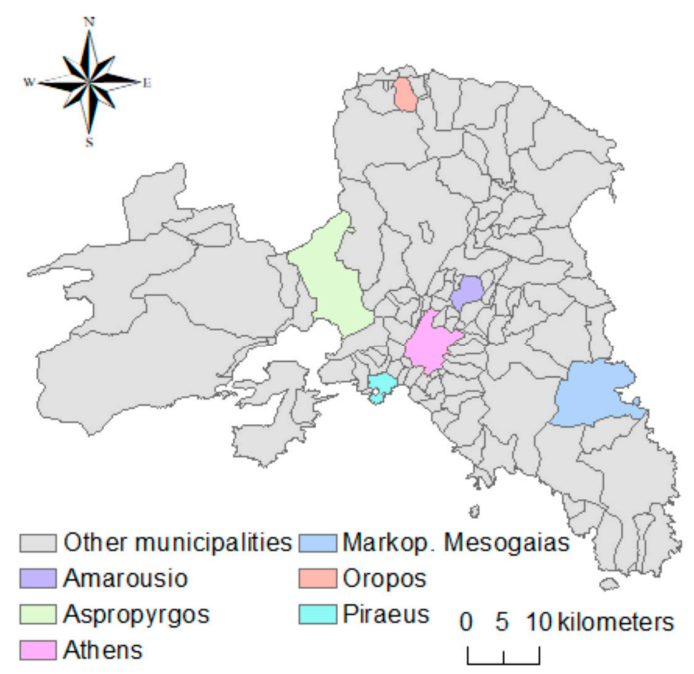

Figure 1. Municipal boundaries illustrating urban centers (and sub-centers) in Attica.

\subsection{Data Analysis}

The spatial distribution of the main indicator adopted in this study (population living in sparse settlements) was illustrated using maps and descriptive statistics. A step-wise multiple regression analysis was run to identify relevant factors shaping the spatial distribution of sparse population over time, considering the percent share of population living in sparse settlements in total resident population as the dependent variable and the background indicators described in Section 2.2 as predictors. A forward step-wise approach was adopted with the aim to identify the most relevant, non-collinear predictors within the broad set of candidate variables potentially influencing the spatial distribution of sparse population. Predictors were selected by fixing a F-to-enter threshold to 5 and a F-to-remove threshold to 2.5. Only models with significant adjusted $R^{2}$ and predictor's coefficients were considered in the final analysis. Adjusted $\mathrm{R}^{2}$ and Durbin-Watson test for serial correlation 
were evaluated when assessing the goodness-of-fit of each model selected in the forward step-wise procedure. To reduce the impact of (more or less intense) deviations from normality, variables were standardized prior to analysis.

\section{Results}

\subsection{Descriptive Analysis of Sparse Settlements in Attica}

Figure 2 illustrates the spatial distribution of sparse settlements in the study area at the beginning and the end of the investigation period. In 1951, sparse settlements were distributed in a heterogeneous and fragmented way across the Athens' metropolitan region, being located in both the peri-urban fringe around Athens and in more remote and rural sites of northeastern Attica. With urban expansion, sparse settlements in 2011 were observed progressively far away from Athens, concentrating along the Aegean Sea coastline in northern and Eastern Attica, at distances ranging between $30 \mathrm{~km}$ and 40 $\mathrm{km}$ from downtown Athens. Such transformations are coherent with the progressive expansion of residential settlements involving traditionally rural municipalities in the outskirts of Athens.
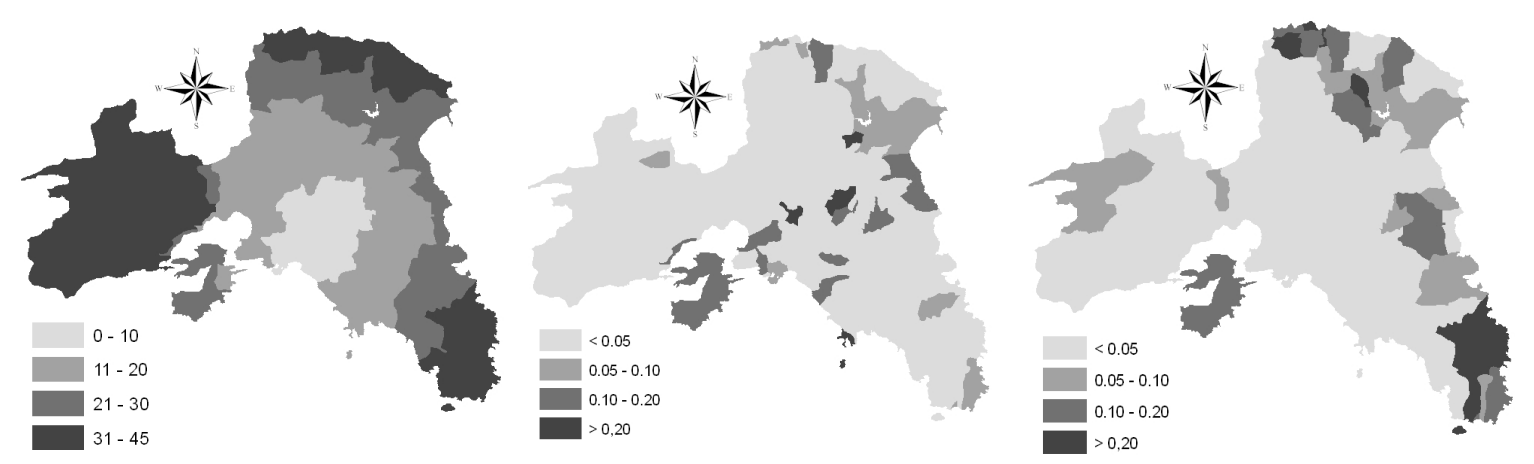

Figure 2. Average linear distance of each municipality to downtown Athens (left). Density of sparse settlements (per $\mathrm{km}^{2}$ ) in the study area (middle: 1951; right: 2011).

\subsection{Spatial Distribution of Sparse Population in Attica}

Figure 3 illustrates the progressive decline of sparse population in the study area between 1961 and 2011. Percent share of population living in sparse settlements in total resident population at municipal scale decreased continuously over time (from more than 30\% in 1961 to less than $10 \%$ in 2011). Spatial variability in this indicator declined over time, being the lowest in 2011, when municipalities with more than $30 \%$ population living in sparse settlements were rather scarce compared with 1961, when municipalities with sparse population $>50 \%$ of total population were relatively common in both rural districts and areas around Greater Athens. The spatial distribution of population living in sparse settlements was relatively radio-centric, increasing with the distance with downtown Athens and being negatively influenced by topography and road accessibility (Figure 4). Sparse settlements were relatively common in all municipalities around Greater Athens in 1961 and decreased in number and population size in the following two decades. Since 1991, population in sparse settlements remained higher than $60 \%$ of total population only in scattered municipalities southeast and west of Athens, especially in rural and economically-disadvantaged districts of Thriasio-Megara (Western Attica) and Keratea-Lavrio (Eastern Attica). In 2011, only a few municipalities located in Northern and Eastern Attica had a share of population living in sparse settlements above $30 \%$. 


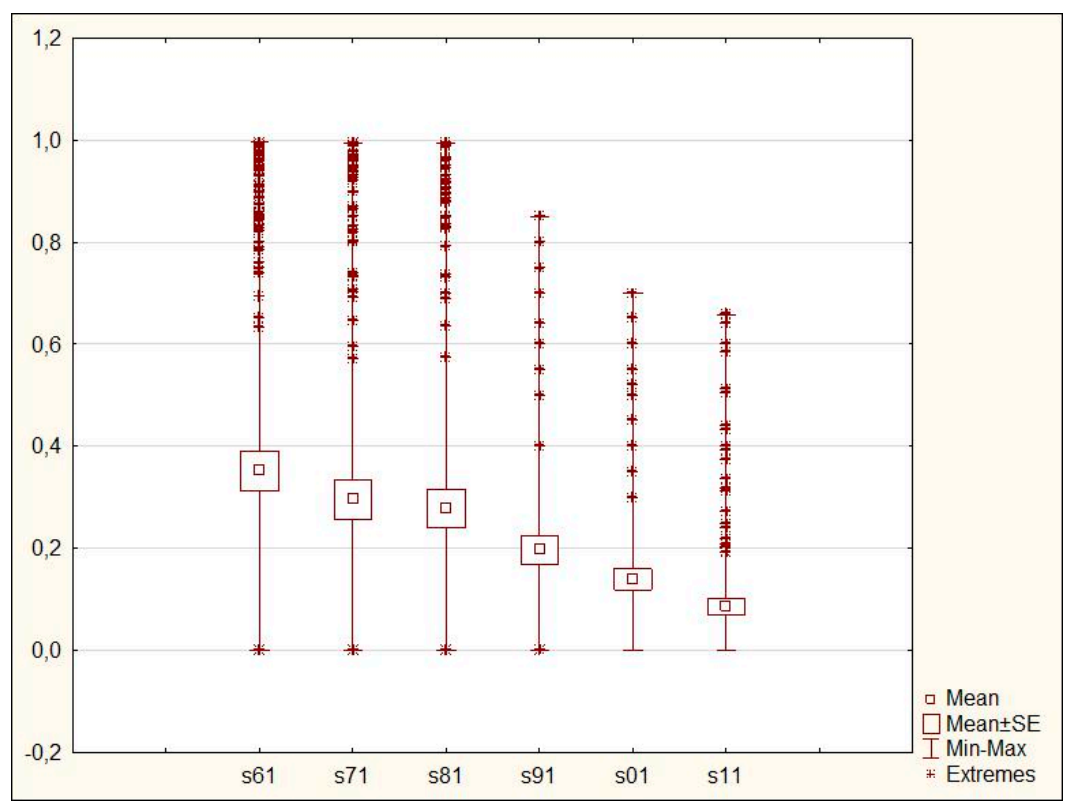

Figure 3. Box and Whisker diagram illustrating the statistical distribution of the dependent variable (relative proportion of population living in sparse settlements in total resident population at the municipal scale, namely 's61', ... , 's11') in the Athens' metropolitan region, selected years from 1961 to 2011.

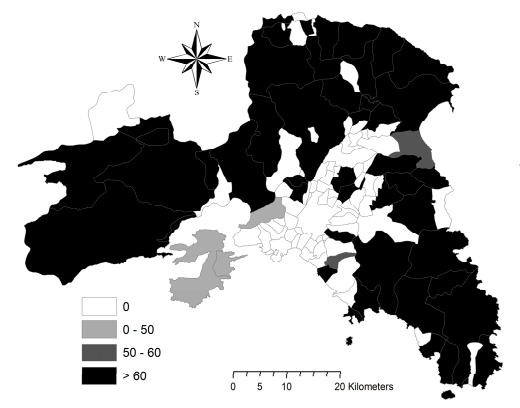

1961

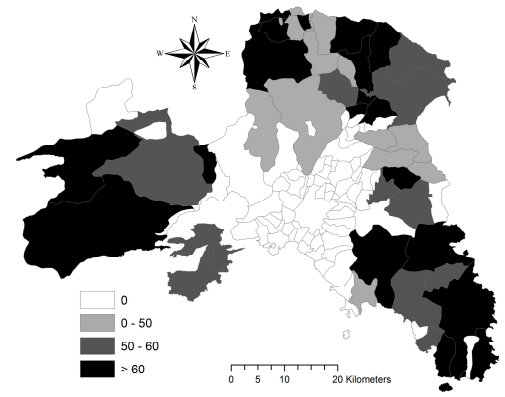

1991

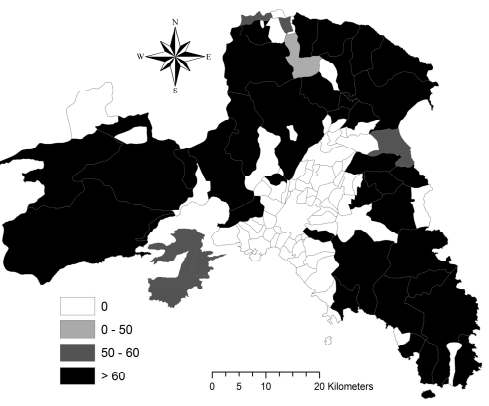

1971

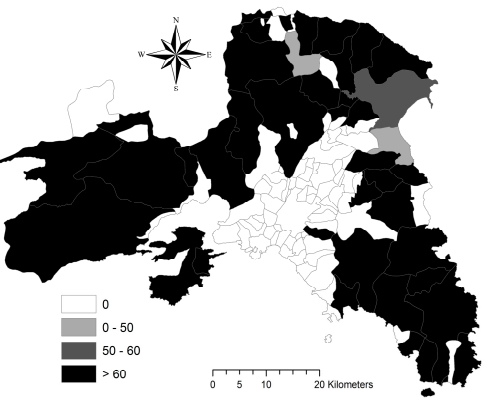

1981

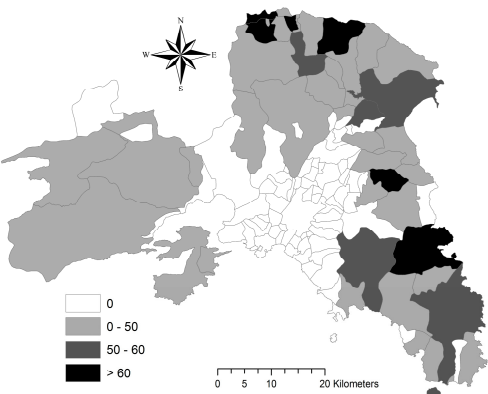

2001

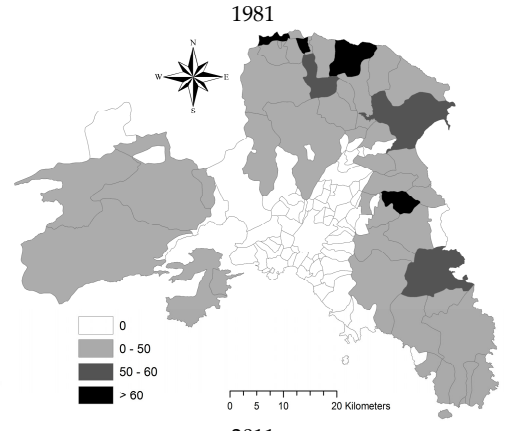

2011

Figure 4. Percent share of population living in sparse settlements in total resident population by year and municipality, Athens metropolitan region.

\subsection{A Step-Wise Regression of Socioeconomic Predictors of Sparse Population in Attica}

Table 1 illustrates step-wise regression models identifying the most relevant predictors that may explain the spatial distribution of sparse population in metropolitan Attica over the study period. Models received relatively high adjusted $\mathrm{R}^{2}$ all over the study period, increasing from 0.45 in 1961 to 0.51 in 2011 and reaching a peak of 0.55 in 2001. Values of the Durbin-Watson test were systematically close to 2, indicating a negligible serial autocorrelation. Distance from downtown Athens was the most significant predictor over a relatively long time period between 1961 and 1991, indicating the predominance of a radio-centric expansion that preceded a more latent phase 
of dispersed urban growth. The regression coefficient for this predictor was the highest in 1971 (reflecting the particularly compact and hyper-dense structure characterizing the Greater Athens' area in that period) and declined moderately afterwards. Distance from Markopoulo Messoghias, the main center in the Messoghia district, was negatively associated with sparse population. Regression coefficients were particularly high at the beginning of the study period, decreasing progressively in more recent decades, except for 2001. Municipal size is another predictor associated positively with sparse population. Municipalities administering a larger area-that are usually destined to non-urban use, such as cropland or forests-had a larger density of sparse settlements. Tourism specialization and average farm size were predictors related positively with sparse population only in 1961.

Table 1. Results of step-wise multiple regression models with background socioeconomic variables as predictors of population living in sparse settlements (dependent variable) in the study area by year (significance at ${ }^{*} p<0.05,{ }^{* *} p<0.001 ; \mathrm{SE}$ means standard error).

\begin{tabular}{|c|c|c|c|c|c|c|c|c|c|c|c|c|}
\hline \multirow{2}{*}{ Variab. } & \multicolumn{4}{|c|}{1961} & \multicolumn{4}{|c|}{1971} & \multicolumn{4}{|c|}{1981} \\
\hline & B & SE & $t_{(108)}$ & $p$ & B & SE & $t_{(110)}$ & $p$ & B & $\mathrm{SE}$ & $t_{(110)}$ & $p$ \\
\hline dAth & 0.905 & 0.236 & 3.84 & $0.0002 * *$ & 1.056 & 0.231 & 4.56 & 0.0000 ** & 0.998 & 0.225 & 4.44 & $0.0000^{* *}$ \\
\hline Area & 0.332 & 0.081 & 4.12 & $0.0001 * *$ & 0.339 & 0.080 & 4.23 & $0.0000 * *$ & 0.390 & 0.078 & 5.00 & $0.0000^{* *}$ \\
\hline dMak & -0.620 & 0.187 & -3.31 & 0.0013 * & -0.632 & 0.186 & -3.39 & 0.0010 * & -0.630 & 0.181 & -3.48 & $0.0007^{* *}$ \\
\hline $\mathrm{dAsp}$ & -0.483 & 0.207 & -2.33 & 0.0215 * & -0.531 & 0.206 & -2.58 & 0.0112 * & -0.478 & 0.200 & -2.39 & 0.0186 * \\
\hline$t$ & 0.190 & 0.070 & 2.71 & $0.0079^{*}$ & & & & & & & & \\
\hline Afs & 0.190 & 0.082 & 2.31 & 0.0226 * & & & & & & & & \\
\hline Adj-R $R^{2}$ & \multicolumn{4}{|c|}{0.454} & \multicolumn{4}{|c|}{0.455} & \multicolumn{4}{|c|}{0.486} \\
\hline \multirow[t]{3}{*}{ DW test* } & \multicolumn{4}{|c|}{1.90} & \multicolumn{4}{|c|}{1.98} & \multicolumn{4}{|c|}{1.91} \\
\hline & \multicolumn{4}{|c|}{1991} & \multicolumn{4}{|c|}{2001} & \multicolumn{4}{|c|}{2011} \\
\hline & B & SE & $t_{(110)}$ & $p$ & B & SE & $t_{(110)}$ & $p$ & B & SE & $t_{(108)}$ & $p$ \\
\hline dAth & 0.663 & 0.081 & 8.18 & $0.0000 * *$ & & & & & & & & \\
\hline Area & 0.362 & 0.076 & 4.75 & $0.0000^{* *}$ & 0.318 & 0.073 & 4.34 & $0.0000 * *$ & 0.412 & 0.107 & 3.85 & $0.0002^{* *}$ \\
\hline dMak & -0.368 & 0.089 & -4.15 & $0.0001^{* *}$ & -0.740 & 0.109 & -6.76 & $0.0000 * *$ & -0.358 & 0.203 & -1.77 & 0.0800 * \\
\hline dAsp & & & & & & & & & 0.307 & 0.149 & 2.06 & 0.0414 * \\
\hline dOro & -0.189 & 0.077 & -2.47 & 0.0149 * & -0.758 & 0.100 & -7.58 & $0.0000 * *$ & -0.734 & 0.123 & -5.98 & $0.0000^{* *}$ \\
\hline dMar & & & & & 1.000 & 0.106 & 9.39 & $0.0000 * *$ & 0.566 & 0.218 & 2.60 & 0.0107 * \\
\hline Ele & & & & & & & & & -0.275 & 0.099 & -2.78 & 0.0063 * \\
\hline Adj-R $R^{2}$ & \multicolumn{4}{|c|}{0.535} & \multicolumn{4}{|c|}{0.548} & \multicolumn{4}{|c|}{0.509} \\
\hline DW test* & \multicolumn{4}{|c|}{1.96} & \multicolumn{4}{|c|}{1.97} & \multicolumn{4}{|c|}{1.96} \\
\hline
\end{tabular}

* Durbin-Watson statistic results.

Between 1961 and 1981, distance from Aspropyrgos, a rural center in Thriasio district, was negatively associated with sparse population as observed for the distance from Markopoulo Messoghias. Interestingly, the same predictors displayed a positive relation with the dependent variable in 2011, outlining the impact of recent urban expansion, since Aspropyrgos became a peri-urban municipality with mostly compact and semi-dense settlements in recent decades, progressively losing its rural characteristics. Distance from a rural place such as Oropos (Northern Attica) was a significant predictor of sparse population (negative coefficient) only since the early 1990s. At the same time, distance from Maroussi (the new business district northeast of Athens) became an important predictor of sparse population (positive coefficient) in 2001 and 2011. Our analysis clearly outlines how long-term urban dynamics (and especially radio-centric growth of Athens in the earlier decades) have influenced the empirical results of the models.

\section{Discussion}

Multifaceted processes of landscape 'co-evolution' among urban expansion and peri-urban contexts around metropolitan areas have been identified over the last decades, leading urban and rural elements to coexistence and latent conflicts [68]. Landscape transformations were more intense in local contexts where resident population increased quickly due to suburbanization processes and where ecosystems are more fragile due to specific land conditions $[9,12,13,15,18,36,39,69-80]$. Related to this, the Attica region experienced soil consumption and rural changes producing negative environmental externalities $[34,35,81]$. Furthermore, in recent years with economic crisis, a small but increasing 
number of residents in Greek cities (especially in Athens and Salonika) declares the willingness to leave their city with the purpose to work in the primary sector $[1,49,68]$.

In this line of thinking, sprawl dynamics led to a new form of peri-urban landscape, possibly associated with a new definition of 'rurality'. In 1951, the spatial distribution of sparse settlements was heterogeneous and fragmented across the Athens' metropolitan region; sparse settlements were located in both the peri-urban fringe around Athens and in more remote and rural locations of northeastern Attica; in 2011, sparse settlements were exclusively found far away from Athens, being concentrated along the Aegean sea coastline in northern and Eastern Attica [52]. Furthermore, spatial variability and percent share of population living in sparse settlements in total resident population at a municipal scale decreased continuously over time. Spatial variability was the lowest in 2011, when municipalities with more than 30\% of population living in sparse settlements were rather scarce compared with 1961, when municipalities with sparse population $>50 \%$ of total population were relatively common in both rural districts and peri-urban areas around Greater Athens.

The empirical results of the study contribute to understanding a complex mechanism of urban/rural development involving sequential stages of metropolitan growth (compact expansion, dispersion, re-densification, etc.) seen from the 'other side of the fringe', i.e., considering the increasing landscape mix in rural districts now becoming more mixed and entropic, as typical of many peri-urban areas across Europe and in other advanced economies. Athens has experienced one of the fastest expansions of resident population, income and dispersed settlements in southern Europe $[63,64]$. Related to this, the regression analysis offers a more comprehensive interpretation of Athens expansion and changes in the related socioeconomic context providing evidence of the dominance of a typical radio-centric structure up to the 1990s and the emergence of new settlement forms-oriented toward urban dispersion-in the following decades. Distance from Athens resulted in the most relevant predictor of the spatial distribution of sparse population between 1961 and 1991, demonstrating the prevalence of a radio-centric development that preceded a more latent phase of dispersed urban growth, being more influenced by spatial proximity and elevation. Since 1991, sparse settlements were concentrated in southeastern and western municipalities near Athens; in 2011, only a few municipalities located in Northern and Eastern Attica had a share of population living in sparse settlements above $30 \%$. At the same time, new distance indicators (e.g., distance from Maroussi) became significant in 2001 and 2011, suggesting the role of (more or less planned) processes of residential and economic dispersion in delocalized places.

The spatial gap among the metropolitan area of Athens and the rest of Greece, and even among the city of Athens with respect to its metropolitan area, brings out a territorial polarization that expresses a set of factors that justify the uneven socioeconomic disparities between urban and rural areas, almost because of the consolidated dominance of Athens over the metropolitan hierarchy $[47,51,54]$. The Athens' metropolitan region was traditionally organized in a mono-centric structure [7], where urban settlements are concentrated around the capital city, and rural areas extend the remaining part of Attica [29,68]. A trend toward discontinuous urban expansion was detected since the 1980s in Athens [82,83], with occurrence of medium-low density settlements [6,43,47,84]. Distance from other centers (e.g., Markopoulo Messoghias) was negatively associated with sparse population. In addition, municipal size is positively associated with sparse population since larger municipalities may state more permits for sparse buildings.

Between 1961 and 1981, distances from the rural centers of Aspropyrgos and Markopoulo Messoghias were negatively associated with sparse population. The same predictors in 2011 displayed a positive relation with the dependent variable, outlining the impact of recent urban expansion, since Aspropyrgos became a peri-urban municipality with compact and semi-dense settlements, progressively losing its rural characteristics. Distance from a rural place, e.g., Oropos (Northern Attica), was a significant predictor of sparse population (negative coefficient) only since the early 1990s. Distance from Maroussi (the new business district north-east of Athens) became an additional predictor for sparse population in 2001 and 2011. Our analysis clearly outlines how long-term urban 
dynamics (and especially the radio-centric growth of Athens) seriously affected the empirical results of the regression models.

Based on these premises, spatial planning should find a joint vision of spatial, economic and social combination among 'rurality' and industrial modernity [85]. By proposing new forms of sustainable development in traditional contexts $[2,49,79]$, a new concept of 'rurality' should be increasingly faced with current landscapes that mix scattered settlements and fragmented cropland and are exposed to increasingly volatile economic downturns [86-103]. In this regard, rural development is increasingly constrained by competition with non-agriculture, productive land-use (e.g., residential and industrial settlements, infrastructure and logistics). General principles of rural development in mixed peri-urban districts indicate that a stable and balanced socioeconomic local context is a key component when endorsing an effective and sustainable use [40,52], which depends on different interacting elements of local sustainability, including demography, environment, social cohesion and poverty alleviation [104,105]. In the study area, rural development issues add to a relatively complex mechanism of urban expansion, based on planning deregulation, ineffective zoning and informal building at least up to the late 1980s. More recent strategies of spatial (town and regional) planning have indicated a clearer direction toward centralized and formal zoning rules and land management, e.g., introducing planning constraints to building in rural areas and a more strict regime of environmental protection addressing national and European regulations [106,107]. Implications of our study are important when designing strategies for sustainable urban form and promoting urban containment in de-regulated metropolitan contexts.

\section{Conclusions}

Spatio-temporal dynamics of sparse settlements may reflect resilience and compliance of Mediterranean peri-urban landscapes to rapidly-changing socio-demographic circumstances over time $[9,17,25]$. Based on this framework, territorial heterogeneity, topographic complexity and urbanization-driven land fragmentation are a pertinent challenge for policy makers and land managers $[12,15,108-116]$. Under the assumption that regional transformations influence (positively or negatively) local socioeconomic systems, the resulting environmental conditions require extensive monitoring and spatially-explicit policies derived from a comprehensive socio-ecological vision. In this line of thinking, landscape transformations can be more effectively governed by multi-level policies joining short-term and long-term socioeconomic goals, including short-term economic cycles (expansion vs. recession) and structural changes covering a longer time horizon.

Author Contributions: L.S. and R.S. conceived and designed the study; I.Z. and M.C. prepared the database; P.S. analyzed the data; L.S. and R.S. wrote the paper.

Funding: This research received no external funding.

Conflicts of Interest: The authors declare no conflict of interest.

\section{References}

1. Cecchini, M.; Zambon, I.; Pontrandolfi, A.; Turco, R.; Colantoni, A.; Mavrakis, A.; Salvati, L. Urban spraw1 and the 'olive'landscape: Sustainable land management for 'crisis' cities. GeoJournal 2018, 1-19. [CrossRef]

2. Colantoni, A.; Delfanti, L.; Recanatesi, F.; Tolli, M.; Lord, R. Land use planning for utilizing biomass residues in Tuscia Romana (central Italy): Preliminary results of a multi criteria analysis to create an agro-energy district. Land Use Policy 2016, 50, 125-133. [CrossRef]

3. Salvati, L. Agro-forest landscape and the 'fringe'city: A multivariate assessment of land-use changes in a sprawling region and implications for planning. Sci. Total. Environ. 2014, 490, 715-723. [CrossRef] [PubMed]

4. Salvati, L. From Sprawl to Compactness and Back: Long-term Population Dynamics (1848-2011) and the Economic Structure of a Mediterranean city. GeoJournal 2016, 81, 319-332. [CrossRef]

5. Salvati, L.; Ferrara, C. Do changes in vegetation quality precede urban sprawl? Area 2013, 45, 365-375. [CrossRef]

6. Salvati, L.; Zitti, M.; Sateriano, A. Changes in city vertical profile as an indicator of sprawl: Evidence from a Mediterranean urban region. Habitat Int. 2013, 38, 119-125. [CrossRef] 
7. Zambon, I.; Sauri, D.; Serra, P.; Carlucci, M.; Salvati, L. Beyond the 'Mediterranean city': Socioeconomic disparities and urban sprawl in three Southern European cities. Geogr. Ann. Ser. B Hum. Geogr. 2017, 99, 319-337. [CrossRef]

8. Duvernoy, I.; Zambon, I.; Sateriano, A.; Salvati, L. Pictures from the Other Side of the Fringe: Urban Growth and Peri-urban Agriculture in a Post-industrial City (Toulouse, France). J. Rural. Stud. 2018, 57, $25-35$. [CrossRef]

9. Ferrara, A.; Salvati, L.; Sateriano, A.; Carlucci, M.; Gitas, I.; Biasi, R. Unraveling the "stable" landscape: A multi-factor analysis of unchanged agricultural and forest land (1987-2007) in a rapidly-expanding urban region. Urban Ecosyst. 2016, 19, 835-848. [CrossRef]

10. Gkartzios, M.; Remoundou, K.; Garrod, G. Emerging geographies of mobility: The role of regional towns in Greece's 'counterurbanisation story'. J. Rural. Stud. 2017, 55, 22-32. [CrossRef]

11. Gospodini, A. Portraying, classifying and understanding the emerging landscapes in the post-industrial city. Cities 2006, 23, 311-330. [CrossRef]

12. Kizos, T.; Vakoufaris, H. Valorisation of local asset: The case of olive oil on Lesvos Island, Greece. Food Policy 2011, 36, 705-714. [CrossRef]

13. Kristensen, S.P.; Thenail, C.; Kristensen, L. Farmers' involvement in landscape: An analysis of the relationship between farm location, farm characteristics and landscape changes in two study areas in Jutlund, Denmark. J. Environ. Manag. 2001, 61,301-318. [CrossRef] [PubMed]

14. Makhzoumi, J.M. The changing role of rural landscapes: Olive and carob multi-use tree plantations in the semiarid Mediterranean. Landsc. Urban Plan. 1997, 37, 115-122. [CrossRef]

15. Sabbi, A.; Salvati, L. Seeking for a Downward Spiral? Soil Erosion Risk, Agro-forest landscape and Socioeconomic Conditions in Italian local communities. Land Use Policy 2015, 41, 388-396. [CrossRef]

16. Salvati, L.; Ferrara, A. Do land cover changes shape sensitivity to forest fires in peri-urban areas? Urban For. Urban Green. 2014, 13, 571-575. [CrossRef]

17. Salvati, L.; Gasparella, L.; Munafò, M.M.; Romano, R.; Barbati, A. Figuring the features of the Roman Campagna: Recent landscape structural transformations of Rome's countryside. Ann. Silvic. Res. 2017, 41, 20-28.

18. Serra, P.; Pons, X.; Saurì, D. Land-cover and land-use change in a Mediterranean landscape: A spatial analysis of driving forces integrating biophysical and human factors. Appl. Geogr. 2008, 28, 189-209. [CrossRef]

19. Colantoni, A.; Mavrakis, A.; Sorgi, T.; Salvati, L. Towards a 'polycentric' landscape? Reconnecting fragments into an integrated network of coastal forests in Rome. Rendiconti Accademia Nazionale dei Lincei 2015, 26, 615-624. [CrossRef]

20. Estel, S.; Kuemmerle, T.; Alcántara, C.; Levers, C.; Prishchepov, A.; Hostert, P. Mapping farmland abandonment and recultivation across Europe using MODIS NDVI time series. Remote. Sens. Environ. 2015, 163, 312-325. [CrossRef]

21. Kizos, T. Multifunctionality of farm households in Greece. Nor. Geogr. Tidsskr. Nor. J. Geogr. 2010, 64, $105-116$. [CrossRef]

22. Kizos, T.; Vasdeki, M.; Chatzikiriakou, C.; Dimitriou, D. 'For my children': Different functions of the agricultural landscape and attitudes of farmers on different areas of Greece towards small scale landscape change. Geogr. Tidsskr. Dan. J. Geogr. 2011, 111, 117-130. [CrossRef]

23. Zambon, I.; Ferrara, A.; Salvia, R.; Mosconi, E.M.; Fici, L.; Turco, R.; Salvati, L. Rural Districts between Urbanization and Land Abandonment: Undermining Long-Term Changes in Mediterranean Landscapes. Sustainability 2018, 10, 1159. [CrossRef]

24. Baró, F.; Palomo, I.; Zulian, G.; Vizcaino, P.; Haase, D.; Gómez-Baggethun, E. Mapping ecosystem service capacity, flow and demand for landscape and urban planning: A case study in the Barcelona metropolitan region. Land Use Policy 2016, 57, 405-417. [CrossRef]

25. Ceccarelli, T.; Bajocco, S.; Perini, L.; Salvati, L. Urbanisation and Land Take of High Quality Agricultural Soils-Exploring Long-term Land Use Changes and Land Capability in Northern Italy. Int. J. Environ. Res. 2014, 8, 181-192.

26. Salvati, L.; Ferrara, A.; Tombolini, I.; Gemmiti, R.; Colantoni, A.; Perini, L. Desperately Seeking Sustainability: Urban Shrinkage, Land Consumption and Regional Planning in a Mediterranean Metropolitan Area. Sustainability 2015, 7, 11980-11997. [CrossRef]

27. Colantoni, A.; Ferrara, C.; Perini, L.; Salvati, L. Assessing Trends in Climate Aridity and Vulnerability to Soil Degradation in Italy. Ecol. Indic. 2015, 48, 599-604. [CrossRef] 
28. Colantoni, A.; Grigoriadis, E.; Sateriano, A.; Venanzoni, G.; Salvati, L. Cities as selective land predators? A lesson on urban growth, deregulated planning and sprawl containment. Sci. Total. Environ. 2016, 545, 329-339. [CrossRef] [PubMed]

29. Colantoni, A.; Grigoriadis, E.; Sateriano, A.; Sarantakou, E.; Salvati, L. Back to Von Thunen: A Southern European perspective on mono-centric urban growth, economic structure and non-urban land decline. Int. Plan. Stud. 2017, 22, 173-188. [CrossRef]

30. Tanrivermis, H. Agricultural land use change and sustainable use of land resources in the Mediterranean region of Turkey. J. Arid. Environ. 2003, 54, 553-564. [CrossRef]

31. Zambon, I.; Colantoni, A.; Carlucci, M.; Morrow, N.; Sateriano, A.; Salvati, L. Land quality, sustainable development and environmental degradation in agricultural districts: A computational approach based on entropy indexes. Environ. Impact Assess. Rev. 2017, 64, 37-46. [CrossRef]

32. Garcia Latorre, J.; Garcia-Latorre, J.; Sanchez-Picon, A. Dealing with aridity: Socio-economic structures and environmental changes in an arid Mediterranean region. Land Use Policy 2001, 18, 53-64. [CrossRef]

33. Schneider, A.; Woodcock, C.E. Compact, dispersed, fragmented, extensive? A comparison of urban growth in twenty-five global cities using remotely sensed data, pattern metrics and census information. Urban Stud. 2008, 45, 659-692. [CrossRef]

34. Salvati, L.; Tombolini, I.; Gemmiti, R.; Carlucci, M.; Bajocco, S.; Perini, L.; Ferrara, A.; Colantoni, A. Complexity in action: Untangling latent relationships between land quality, economic structures and socio-spatial patterns in Italy. PLoS ONE 2015, 12, e0177853. [CrossRef] [PubMed]

35. Salvati, L. Urban expansion and high-quality soil consumption-An inevitable spiral? Cities 2013, 31, 349-356. [CrossRef]

36. Pereira, P.; Brevik, E.C.; Muñoz-Rojas, M.; Miller, B.A.; Smetanova, A.; Depellegrin, D.; Misiune, I.; Novara, A.; Cerdà, A. Chapter 2-Soil Mapping and Processes Modeling for Sustainable Land Management. Soil Map. Process Model. Sustain. Land Use Manag. 2017, 29-60. [CrossRef]

37. Salvati, L.; Bajocco, S.; Ceccarelli, T.; Zitti, M.; Perini, L. Towards a process-based evaluation of soil vulnerability to degradation: A spatio-temporal approach in Italy. Ecol. Indic. 2011, 11, 1216-1227. [CrossRef]

38. Mavrakis, A.; Colantoni, A.; Salvati, L. Soil degradation, landscape and climate variations in a Mediterranean agro-forest system (Thriasio, Greece): Proposal for a desertification indicator using time series analysis. Int. J. Agric. Resour. Gov. Ecol. 2014, 10, 335-343. [CrossRef]

39. Zambon, I.; Benedetti, A.; Ferrara, C.; Salvati, L. Soil Matters? A Multivariate Analysis of Socioeconomic Constraints to Urban Expansion in Mediterranean Europe. Ecol. Econ. 2018, 146, 173-183. [CrossRef]

40. Hall, P. The future of the metropolis and its form. Reg. Stud. 1997, 31, 211-220. [CrossRef]

41. Parr, J. The Regional Economy, Spatial Structure and Regional Urban Systems. Reg. Stud. 2014, 48, $1926-1938$. [CrossRef]

42. Salvati, L.; Serra, P. Estimating rapidity of change in complex urban systems: A multidimensional, local-scale approach. Geogr. Anal. 2016, 48, 132-156. [CrossRef]

43. Arapoglou, V.P.; Sayas, J. New facets of urban segregation in Southern Europe. Eur. Urban Reg. Stud. 2009, 16, 345-362. [CrossRef]

44. Di Feliciantonio, C.; Salvati, L. 'Southern' alternatives of urban diffusion: Investigating settlement characteristics and socioeconomic patterns in three Mediterranean regions. Tijdschr. Econ. Soc. Geogr. 2015, 106, 453-470. [CrossRef]

45. Maloutas, T. Segregation and residential mobility: Spatially entrapped social mobility and its impact on segregation in Athens. Eur. Urban Reg. Stud. 2004, 11, 195-211. [CrossRef]

46. Carlucci, M.; Grigoriadis, E.; Rontos, K.; Salvati, L. Revisiting an Hegemonic Concept: Long-term 'Mediterranean Urbanization' in between city re-polarization and metropolitan decline. Appl. Spat. Anal. Policy 2017, 10, 347-362. [CrossRef]

47. Chorianopoulos, I.; Pagonis, T.; Koukoulas, S.; Drymoniti, S. Planning, competitiveness and sprawl in the Mediterranean city: The case of Athens. Cities 2010, 27, 249-259. [CrossRef]

48. Chorianopoulos, I.; Tsilimigkas, G.; Koukoulas, S.; Balatsos, T. The shift to competitiveness and a new phase of sprawl in the Mediterranean city: Enterprises guiding growth in Messoghia-Athens. Cities 2014, 39, 133-143. [CrossRef]

49. Gkartzios, M. 'Leaving Athens': Narratives of counterurbanisation in times of crisis. J. Rural. Stud. 2013, 32, 158-167. [CrossRef] 
50. Rontos, K.; Grigoriadis, E.; Sateriano, A.; Syrmali, M.; Vavouras, I.; Salvati, L. Lost in protest, found in segregation: Divided cities in the light of the 2015 "Oxı" referendum in Greece. City Cult. Soc. 2016, 7, 139-148. [CrossRef]

51. Souliotis, N. Cultural economy, sovereign debt crisis and the importance of local contexts: The case of Athens. Cities 2013, 33, 61-68. [CrossRef]

52. Zitti, M.; Ferrara, C.; Perini, L.; Carlucci, M.; Salvati, L. Long-term urban growth and land use efficiency in Southern Europe: Implications for sustainable land management. Sustainability 2015, 7, 3359-3385. [CrossRef]

53. Ferrara, C.; Carlucci, M.; Grigoriadis, E.; Corona, P.; Salvati, L. A comprehensive insight into the geography of forest cover in Italy: Exploring the importance of socioeconomic local contexts. For. Policy Econ. 2017, 75, 12-22. [CrossRef]

54. Rontos, K.; Zitti, M.; Salvati, L. Past, Present and Future: Expansion with (and without) growth in urban systems under a structural crisis. Theor. Empir. Res. Urban Manag. 2017, 12, 16-31.

55. Gkartzios, M.; Remoundou, K. Language struggles: Representations of the countryside and the city in an era of mobilities. Geoforum 2018, 93, 1-10. [CrossRef]

56. Bell, M.M.; Osti, G. Mobilities and ruralities: An introduction. Sociol. Rural. 2010, 50, 199-204. [CrossRef]

57. Stockdale, A. Contemporary and 'messy'rural in-migration processes: Comparing counterurban and lateral rural migration. Popul. Space Place 2016, 22, 599-616. [CrossRef]

58. Milbourne, P. Re-populating rural studies: Migrations, movements and mobilities. J. Rural Stud. 2007, 23, 381-386. [CrossRef]

59. Benson, M.; O'reilly, K. Migration and the search for a better way of life: A critical exploration of lifestyle migration. Sociol. Rev. 2009, 57, 608-625. [CrossRef]

60. Gkartzios, M.; Scott, K. A Cultural Panic in the Province? Counterurban Mobilities, Creativity, and Crisis in Greece. Popul. Space Place 2015, 21, 843-855. [CrossRef]

61. Murdoch, J.; Lowe, P.; Ward, N. The Differentiated Countryside; Routledge: Abingdon, UK, 2003.

62. Gkartzios, M.; Scott, M. Placing housing in rural development: Exogenous, endogenous and neo-endogenous approaches. Sociol. Rural. 2014, 54, 241-265. [CrossRef]

63. Gargiulo Morelli, V.; Rontos, K.; Salvati, L. Between suburbanisation and re-urbanisation? Revisiting the Urban Life Cycle in a Mediterranean Compact City. Urban Res. Pract. 2014, 7, 74-88. [CrossRef]

64. Kallis, G. Co-evolution in water resource development. The vicious cycle of water supply and demand in Athens, Greece. Ecol. Econ. 2010, 69, 796-809. [CrossRef]

65. De Rosa, S.; Salvati, L. Beyond a 'side street story'? Naples from spontaneous centrality to entropic polycentricism, towards a 'crisis city'. Cities 2016, 51, 74-83. [CrossRef]

66. Kaika, M. The economic crisis seen from the everyday. City 2012, 16, 422-430. [CrossRef]

67. Remoundou, K.; Gkartzios, M.; Garrod, G. Conceptualizing mobility in times of crisis: Towards crisis-led counterurbanization? Reg. Stud. 2016, 50, 1663-1674. [CrossRef]

68. Moissidis, A.; Duquenne, M.-N. Peri-urban rural areas in Greece: The case of Attica. Sociol. Rural. 1997, 37, 228-239. [CrossRef]

69. Aretano, R.; Petrosillo, I.; Zaccarelli, N.; Semeraro, T.; Zurlini, G. People perception of landscape change effects on ecosystem services in small Mediterranean islands: A combination of subjective and objective assessments. Landsc. Urban Plan. 2013, 112, 63-73. [CrossRef]

70. Beriatos, E.; Gospodini, A. Glocalising urban landscapes: Athens and the 2004 Olympics. Cities 2004, 21, 187-202. [CrossRef]

71. Biasi, R.; Colantoni, A.; Ferrara, C.; Ranalli, F.; Salvati, L. In-between Sprawl and Fires: Long-term Forest Expansion and Settlement Dynamics at the Wildland-Urban Interface in Rome, Italy. Int. J. Sustain. Dev. World Ecol. 2015, 22, 467-475. [CrossRef]

72. Cimini, D.; Tomao, A.; Mattioli, W.; Barbati, A.; Corona, P. Assessing impact of forest cover change dynamics on high nature value farmland in Mediterranean mountain landscape. Ann. Silvic. Res. 2013, 37, $29-37$.

73. Cohen, M.; Bilodeau, C.; Alexandre, F.; Godron, M.; Andrieu, J.; Gresillon, E.; Garlatti, F.; Morganti, A. What is the plant biodiversity in a cultural landscape? A comparative, multi-scale and interdisciplinary study in olive groves and vineyards (Mediterranean France). Agric. Ecosyst. Environ. 2015, 212, 175-186. [CrossRef]

74. Economidou, E. The Attic landscape throughout the centuries and its human degradation. Landsc. Urban Plan. 1993, 24, 33-37. [CrossRef] 
75. Raudsepp-Hearne, C.; Peterson, G.D.; Bennett, E.M. Ecosystem service bundles for analyzing tradeoffs in diverse landscapes. Proc. Natl. Acad. Sci. USA. 2010, 107, 5242-5247. [CrossRef] [PubMed]

76. Salvati, L.; Zitti, M.; Carlucci, M. 'Locked' systems, territorial disparities and sustainability: Economic structure and soil degradation in Italy. Sustainability 2014, 6, 3086-3104. [CrossRef]

77. Tsilimigkas, G.; Kizos, T. Space, pressures and the management of the Greek landscape. Geogr. Ann. Ser. B Hum. Geogr. 2014, 96, 159-175. [CrossRef]

78. Vieri, M. Traditional olive crop mechanization in areas with a high landscape value. Results of tests with new olive picking equipment. Adv. Hortic. Sci. 2002, 16, 235-239.

79. Zambon, I.; Colantoni, A.; Cecchini, M.; Mosconi, E.M. Rethinking sustainability within the viticulture realities integrating economy, landscape and energy. Sustainability 2018, 10, 320. [CrossRef]

80. Barbati, A.; Corona, P.; Salvati, L.; Gasparella, L. Natural forest expansion into suburban countryside: Gained ground for a green infrastructure? Urban For. Urban Green. 2013, 12, 36-43. [CrossRef]

81. Orsini, S. Landscape polarisation, hobby farmers and valuable hills in Tuscany: Understanding landscape dynamics in a peri-urban context. Geogr. Tidsskr. Dan. J. Geogr. 2013, 113, 54-64. [CrossRef]

82. Delladetsima, P.M. The emerging property development pattern in Greece and its impact on spatial development. Eur. Urban Reg. Stud. 2006, 13, 245-278. [CrossRef]

83. Giannakourou, G. Planning regulation, property protection, and regulatory takings in the Greek planning law. Wash. Univ. Glob. Stud. Law Rev. 2006, 5, 534-557.

84. Cuadrado-Ciuraneta, S.; Durà-Guimerà, A.; Salvati, L. Not only tourism: Unravelling suburbanization, second-home expansion and "rural" sprawl in Catalonia, Spain. Urban Geogr. 2017, 38, 66-89. [CrossRef]

85. Fregolent, L.; Vettoretto, L. Land use regulation and social regulation: An unexplored link. Some reflections on the origins and evolution of sprawl in the Veneto "città diffusa". Land Use Policy 2017, 69, 149-159. [CrossRef]

86. Boubaker, K.; Colantoni, A.; Marucci, A.; Longo, L.; Gambella, F.; Cividino, S.; Cecchini, M. Perspective and potential of $\mathrm{CO}_{2}$ : A focus on potentials for renewable energy conversion in the Mediterranean basin. Renew. Energy 2016, 90, 248-256. [CrossRef]

87. Delfanti, L.; Colantoni, A.; Recanatesi, F.; Bencardino, M.; Sateriano, A.; Zambon, I.; Salvati, L. Solar plants, environmental degradation and local socioeconomic contexts: A case study in a Mediterranean country. Environ. Impact Assess. Rev. 2016, 61, 88-93. [CrossRef]

88. Colantoni, A.; Allegrini, E.; Boubaker, K.; Longo, L.; Di Giacinto, S.; Biondi, P. New insights for renewable energy hybrid photovoltaic/wind installations in Tunisia through a mathematical model. Energy Convers. Manag. 2013, 75, 398-401. [CrossRef]

89. Monarca, D.; Cecchini, M.; Guerrieri, M.; Colantoni, A. Conventional and alternative use of biomasses derived by hazelnut cultivation and processing. In Proceedings of the VII International Congress on Hazelnut, Viterbo, Italy, 23-27 June 2008; Volume 845, pp. 627-634.

90. Di Felice, V.; Bessa, E.R.D.J.S.; Mancinelli, R.; Batista, J.G.F.; Campiglia, E. Rurality and agroecosystem sustainability: A case study at farm-field level in Terceira Island (Portugal) and in Viterbo Province (Italy). Renew. Agric. Food Syst. 2014, 29, 265-276. [CrossRef]

91. Ferrara, A.; Salvati, L.; Sabbi, A.; Colantoni, A. Urbanization, Soil Quality and Rural Areas: Towards a Spatial Mismatch? Sci. Total. Environ. 2014, 478, 116-122. [CrossRef] [PubMed]

92. Monarca, D.; Cecchini, M.; Colantoni, A.; Marucci, A. Feasibility of the electric energy production through gasification processes of biomass: Technical and economic aspects. In Proceedings of the International Conference on Computational Science and Its Applications, San Francisco, CA, USA, 19-21 October 2011; Springer: Berlin/Heidelberg, Germany, 2011; pp. 307-315.

93. Colantoni, A.; Marucci, A.; Monarca, D.; Pagniello, B.; Cecchini, M.; Bedini, R. The risk of musculoskeletal disorders due to repetitive movements of upper limbs for workers employed to vegetable grafting. J. Food Agric. Environ. 2012, 10, 14-18.

94. Giourga, C.; Loumou, A. Assessing the impact of pluriactivity on sustainable agriculture. A case study in rural areas of Beotia in Greece. Environ. Manag. 2006, 37, 753-763. [CrossRef] [PubMed]

95. Marchetti, M.; Vizzarri, M.; Lasserre, B.; Sallustio, L.; Tavone, A. Natural capital and bioeconomy: Challenges and opportunities for forestry. Ann. Silvic. Res. 2015, 38, 62-73.

96. Marucci, A.; Zambon, I.; Colantoni, A.; Monarca, D. A combination of agricultural and energy purposes: Evaluation of a prototype of photovoltaic greenhouse tunnel. Renew. Sustain. Energy Rev. 2018, 82, 1178-1186. [CrossRef] 
97. Nuissl, H.; Haase, D.; Lanzendorf, M.; Wittmer, H. Environmental impact assessment of urban land use transitions-A context-sensitive approach. Land Use Policy 2009, 26, 414-424. [CrossRef]

98. Pili, S.; Grigoriadis, E.; Carlucci, M.; Clemente, M.; Salvati, L. Towards Sustainable Growth? A Multi-criteria Assessment of (Changing) Urban Forms. Ecol. Indic. 2017, 76, 71-80. [CrossRef]

99. Salvati, L.; Carlucci, M. The economic and environmental performances of rural districts in Italy: Are competitiveness and sustainability compatible targets? Ecol. Econ. 2011, 70, 2446-2453. [CrossRef]

100. Zambon, I.; Monarca, D.; Cecchini, M.; Bedini, R.; Longo, L.; Romagnoli, M.; Marucci, A. Alternative energy and the development of local rural contexts: An approach to improve the degree of smart cities in the Central-Southern Italy. Contemp. Eng. Sci 2016, 9, 1371-1386. [CrossRef]

101. Zambon, I.; Colantoni, A.; Monarca, D.; Cecchini, M.; Salvati, L. Characterizing Population Dynamics And Early Processes of Urbanization in Rural Tuscia, Central Italy. Rom. J. Reg. Sci. 2017, 11, 76-101.

102. Monarca, D.; Cecchini, M.; Colantoni, A. Plant for the production of chips and pellet: Technical and economic aspects of an case study in the central Italy. In International Conference on Computational Science and Its Applications (ICCSA 2011); Springer: Berlin/Heidelberg, Germany, 2011; pp. 296-306.

103. Corona, P. Forestry research to support the transition towards a bio-based economy. Ann. Silvic. Res. 2015, 38, 37-38.

104. Salvati, L. Neither Ordinary nor Global: A Reflection on the 'Extra-ordinary' Expansion of Athens. Urban Plan. Transp. Res. 2014, 2, 49-56. [CrossRef]

105. Giannakourou, G. Transforming spatial planning policy in Mediterranean countries: Europeanization and domestic change. Eur. Plan. Stud. 2005, 13, 319-331. [CrossRef]

106. Tsilimigkas, G.; Stathakis, D.; Pafi, M. Evaluating the land use patterns of medium-sized Hellenic cities. Urban Res. Pract. 2015, 9, 181-203. [CrossRef]

107. Kizos, T.; Tsilimigkas, G.; Karampela, S. What Drives Built-Up Area Expansion on Islands? Using Soil Sealing Indicators to Estimate Built-Up Area Patterns on Aegean Islands, Greece. Tijdschr. Econ. Soc. Geogr. 2017, 12, 35-52. [CrossRef]

108. Amato, F.; Maimone, B.A.; Martellozzo, F.; Nolè, G.; Murgante, B. The Effects of Urban Policies on the Development of Urban Areas. Sustainability 2016, 8, 297. [CrossRef]

109. Amato, F.; Tonini, M.; Murgante, B.; Kanevski, M. Fuzzy definition of Rural Urban Interface: An application based on land use change scenarios in Portugal. Environ. Model. Softw. 2018, 104, 171-187. [CrossRef]

110. Aubry, R.J.; Abat, M.-H.; Ramamonjisoa, J.; Dabat, M.H.; Rakotoarisoa, J.; Rakotondraibe, J.; Rabeharisoa, L. Urban agriculture and land use in cities: An approach with multi-functionality and sustainsability concepts in the case of Antananarivo (Madagascar). Land Use Policy 2012, 29, 429-439. [CrossRef]

111. Audsley, E.; Pearn, K.R.; Simota, C.; Cojocaru, G.; Koutsidou, E.; Rounsevell, M.D.A.; Trnka, M.; Alexandrov, V. What can scenario modelling tell us aboutfuture European scale agricultural land use and what not? Environ. Sci. Policy 2006, 9, 148-162. [CrossRef]

112. Biasi, R.; Brunori, E.; Smiraglia, D.; Salvati, L. Linking traditional tree-crop landscapes and agro-biodiversity in Central Italy using a database of typical and traditional products: A multiple risk assessment through a data mining analysis. Biodivers. Conserv. 2015, 24, 3009-3031. [CrossRef]

113. Kelly, C.; Ferrara, A.; Wilson, G.A.; Ripullone, F.; Nolè, A.; Harmer, N.; Salvati, L. Community resilience and land degradation in forest and shrubland socio-ecological systems: Evidence in Gorgoglione, Basilicata, Italy. Land Use Policy 2015, 46, 11-20. [CrossRef]

114. Mosquera-Losada, M.R.; Santiago Freijanes, J.J.; Pisanelli, A.; Rois, M.; Smith, J.; den Herder, M.; Ferreiro Domínguez, N. Extent and Success of Current Policy Measures to Promote Agroforestry Across Europe; AGFORWARD European Project Policy Report: Bruxelles, Belgium, 2016.

115. Paul, V.; Haslam Mckenzie, F. Peri-urban farmland conservation and development of alternative food networks: Insights from a case study area in metropolitan Barcelona (Catalonia, Spain). Land Use Policy 2013, 30, 94-105. [CrossRef]

116. Serra, P.; Vera, A.; Tulla, A.F.; Salvati, L. Beyond urban-rural dichotomy: Exploring socioeconomic and land-use processes of change in Spain (1991-2011). Appl. Geogr. 2014, 55, 71-81. [CrossRef]

(C) 2018 by the authors. Licensee MDPI, Basel, Switzerland. This article is an open access article distributed under the terms and conditions of the Creative Commons Attribution (CC BY) license (http:/ / creativecommons.org/licenses/by/4.0/). 